\title{
The effect of ketotifen on inflammatory markers in allergic conjunctivitis: an open, uncontrolled study
} Andrea P Martín ${ }^{1}$, Julio Urrets-Zavalia ${ }^{2}$, Alejandro Berra ${ }^{3}$, Ana Lía Mariani ${ }^{4}$,
Norberto Gallino
Carlos E Baena-Cagnanirdo Gomez Demel ${ }^{6}$, Julio Gagrique Urrets-Zavalia ${ }^{2,8}$ and Horacio M Serra*1,8

Address: ${ }^{1}$ Inmunología, Dpto. Bioquímica Clínica, Facultad Ciencias Químicas, Universidad Nacional de Córdoba, Argentina, ${ }^{2}$ Servicio de Oftalmología, Clínica Reina Fabiola. Córdoba, Argentina, ${ }^{3}$ Dpto. de Patología, Facultad Medicina, Universidad de Buenos Aires, Argentina, ${ }^{4}$ Inmunología, Universidad Nacional de Misiones, Argentina, ${ }^{5}$ Servicio de Alergia e Inmunología, Hospital Privado. Córdoba, Argentina, ${ }^{6}$ Servicio de Oftalmología, Hospital Privado. Córdoba, Argentina, ${ }^{7}$ Servicio de Pediatría, Hospital Infantil Municipal. Córdoba, Argentina and ${ }^{8}$ These authors contributed equally to this work

Email: Andrea P Martín - amartin@bioclin.fcq.unc.edu.ar; Julio Urrets-Zavalia - jauz@arnet.com.ar;

Alejandro Berra - hserra@bioclin.fcq.unc.edu.ar; Ana Lía Mariani - almariani@arnet.com.ar; Norberto Gallino - hprivadoalergia@arnet.com.ar; Eduardo Gomez Demel - oftalmologia_h_priv@cordoba.com.ar; Julio Gagliardi - hprivadoalergia@arnet.com.ar; Carlos E BaenaCagnani - baena@powernet.net.ar; Enrique Urrets-Zavalia - jauz@arnet.com.ar; Horacio M Serra* - hserra@bioclin.fcq.unc.edu.ar

* Corresponding author

Published: 6 January 2003

BMC Ophthalmology 2003, 3:2
Received: 26 September 2002

Accepted: 6 January 2003

This article is available from: http://www.biomedcentral.com/I47I-24I5/3/2

(C) 2003 Martín et al; licensee BioMed Central Ltd. This is an Open Access article: verbatim copying and redistribution of this article are permitted in all media for any purpose, provided this notice is preserved along with the article's original URL.

\begin{abstract}
Background: The efficacy and safety of ketotifen eye drop treatment in allergic conjunctivitis (AC) management is perfectly known by several studies, but the mechanism of action at the biochemical levels is poorly understood so we decided to perform an open, uncontrolled study in order to investigate the effect of the topical administration of ketotifen fumarate $0.05 \%$ on biochemical markers of inflammation on conjunctival cells in patients with AC.
\end{abstract}

Methods: Nineteen patients with symptoms and signs of AC (itching, discharge, burning, redness, increase in the watery discharge, swelling and follicles) and with a history of allergy were prescribed with two daily instillation of one drop of eyewash ketotifen fumarate $0,05 \%$ in both eyes during thirty days. They were studied by measuring clinical and immunologic parameters.

Results: Ketotifen fumarate treatment significantly reduced the total symptoms and signs score for each patient as well as each symptoms and signs at all time points compared with day 0 ( $p<$ 0.0001 and $p<0.016$, respectively). Although the percentage of HLA-DR+ epithelial cells diminished only in $58 \%$ of patients, the numbers of CD29+ and eotaxin + epithelial cells dropped significantly in $68 \%$ and $73 \%$ of them ( $p<0.0062$ and $<0.0082$, respectively) as a consequence of the treatment. In 9 out of 19 patients a simultaneous decrease in the percentage of epithelial cells positive for CD29 and eotaxin was observed.

Conclusion: Ketotifen besides the well-known effect in reducing signs and symptoms of AC significantly diminished production of eotaxin and expression of CD29 by epithelial cells in patients with seasonal AC. 


\section{Background}

Allergic conjunctivitis (AC) is an ocular surface inflammatory disease that affects approximately $25 \%$ of the general population [1-3] and has a significant impact on the social and economic aspects of life. It can appear alone or associated with other allergic diseases, especially allergic rhinitis. AC is an immunopathological disease which the number of mast cells in the substantia propria increase, and also the epithelium becomes densely infiltrated $[4,5]$. Activation of mast cells by IgE bound-receptor crosslinking by allergens promotes the release of several mediators such as histamine, prostaglandins, leukotrienes, tryptase and cytokines, all of them responsible for the symptoms of $\mathrm{AC}$ and the inflammatory changes in conjunctival cells [6-8].

Conjunctival epithelial cells (EC) play an important proinflammatory role in chronic ocular allergic diseases, the expression profile levels of different cellular adhesion molecules and surface inflammatory antigens have been reported in normal and altered human conjunctival epithelium [9-11]. Recent results have demonstrated that expression of ICAM-1 may allow EC to recruit, retain and locally concentrate leukocytes and the presence of HLA$\mathrm{DR}$ raises the question of conjunctival EC antigen presentation [12].

Although the level of expression of CD29 (the common chain of the beta 1 integrins) on normal conjunctival ECs is already known [10], there is not information about changes in its expression during AC. In addition, different epithelial cytokines/chemokines, which are upregulated actively, participate in allergic inflammation [13]. Among those chemokines eotaxin not only play an important role in eosinophilic recruiting and in damaging the tissue, but also maintain this type of immune response [14].

AC can be treated with local anti-allergic agents such as antihistamines, either alone or in combination with alpha-adrenergic agents and mast cell stabilizers [15-18]. Ketotifen fumarate is derived from cyproheptadine, a serotonin and histamine antagonist [19]. The efficacy and safety of this drug treatment in AC management is well known $[20,21]$ and its clinical use has also been widely studied in relation to bronchial asthma where have been demonstrated that ketotifen treatment significantly decreased EG2+ activated eosinophils, CD3+ and CD4+ T cells in the bronchial mucosa and inhibit the expression of E-selectin and ICAM-1 on vascular endothelial cells [22-24].

The effects of different $\mathrm{H} 1$ antihistamines on ICAM-1 expression have been extensively studied [24-29], but since there is not too much information about the effects of ketotifen on expression of CD29, HLA-DR and eotaxin on conjunctival EC during $\mathrm{AC}$, we performed an open, uncontrolled study on patients with AC to investigat the effect of this drug on clinical features and those markers of inflammation.

\section{Methods \\ Human subjects}

Nineteen subjects ( 8 males and 11 females, between 6 and 63 years) with seasonal AC [30] and with a history of allergy (allergic conjunctivitis, hay fever, asthmatic bronchitis and dermatitis) who visited the Department of Ophthalmology, Hospital Privado, Córdoba, Argentina, during the spring season were evaluated. Those patients were diagnosed as previously described [31] based on positive allergen-skin prick test, IgE in tears, conjunctival eosinophils, and symptoms and signs such as itching, discharge, burning, redness, increase in the watery discharge, swelling and presence of follicles. At day 0 they had normal levels of secretory IgA and lisozime and did neither suffer from other eye disorder, nor had they experienced any ophthalmologic treatment in the two previous weeks to their enrollment. The use of contact lenses was suspended for seventy two hours before and during the whole study. All subjects gave informed consent and the study was approved by the ethics committee of the Hospital Privado.

Each patient was prescribed with two daily instillations of one drop of eyewash ketotifen fumarate $0,05 \%$ in both eyes, during thirty days.

\section{Ocular status assessment}

Different symptoms (itching, tearing, burning, redness) and signs (watery discharge increase, swelling, presence of follicles) of allergic conjunctivitis were evaluated at their enrollment (day zero) and at different times after starting treatment $(7,15$ and 30 days). Symptoms and signs were classified in four stages: 0-Absent; 1-Mild; 2-Moderate and 3 -Severe. The total symptoms and signs score (TSSS) for each subject were obtained adding the values of each symptoms and signs divided by the total number of them.

\section{Immunological studies}

Samples of conjunctival scrapings were collected from both eyes of all patients treated on days 0 and 30 using a disposable plastic scoop (Rhino probe ${ }^{\mathrm{TM}}$ ). The $\mathrm{EC}$ obtained were suspended in $20 \% \mathrm{AB}$ human serum - PBS and incubated with anti-CD29 (beta chain of beta 1 integrin) RD1 (COULTER), anti-HLA-DR FITC (Becton Dickinson), and anti-CD45 (Leukocyte common antigen) PerCP (Becton Dickinson) monoclonal antibodies (mAb), or isotopic antibody controls (Becton Dickinson) for $45 \mathrm{~min}$ on ice. Another fraction of the EC was incubated with anti-eotaxin (CCL11) mAb (6H9, kindly provided by LeukoSite Inc., Cambridge, MA) diluted with Triton 


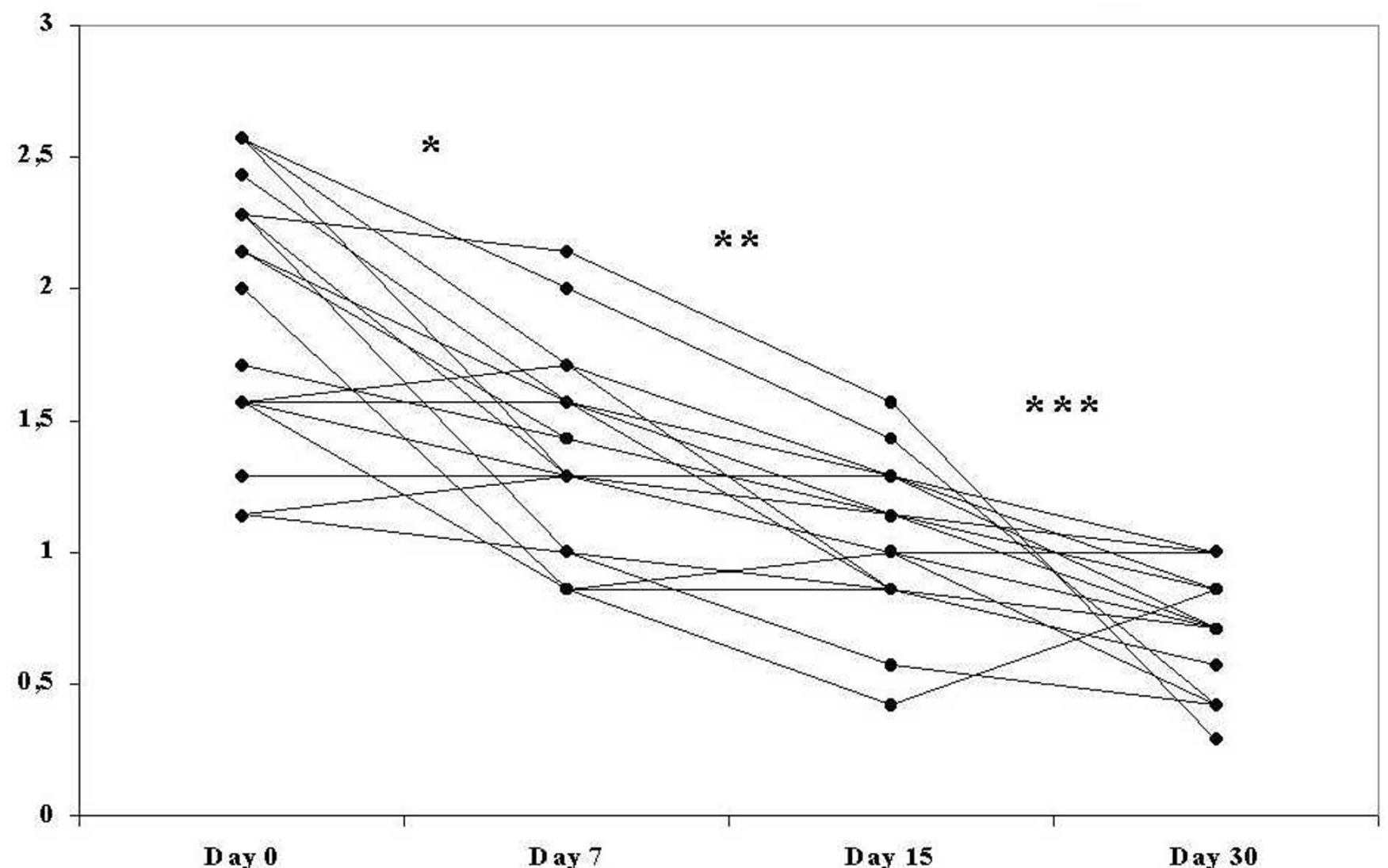

Figure I

Variation of total score of symptoms and signs for each patient with ketotifen treatment. The differences between time points were analyzed by Wilcoxon signed-rank test ${ }^{*}, \mathrm{p}<0.000 \mathrm{I}$, day 0 vs 7,15 and 30 ; and 7 vs 30 ; **, $\mathrm{p}<$ 0.0002 , day 7 vs $15 ; * * *, p<0.0008$ day 15 vs 30 ).

2\%-PBS (Sigma) for 1 hour at $37^{\circ} \mathrm{C}$, then it was incubated with goat anti-mouse IgG FITC (SIGMA) antibody for 30 min on ice and finally with anti-CD45 PerCP (Becton Dickinson) mAb, or isotopic antibody controls (Becton Dickinson) for $45 \mathrm{~min}$ on ice. The samples were properly washed and fixed with paraformaldehyde 1\% and analyzed on a flow cytometer (Cytoron Absolute), equipped with an argon laser emitting at $488 \mathrm{~nm}$. Analytical gates were set to discard cell debris and CD45+ cells. The number of antigen-positive EC was then obtained from a quadrant graphic paper representing mean fluorescence intensities (MFI) on a 3-decade logarithmic amplifier. The upper limit of intensity of fluorescence from the control antibody was regarded as positivity threshold for the tested antibodies. For each sample, 1.000-5.000 EC were analyzed.

\section{Statistical analysis}

Variability of the parameters studied was analyzed with Wilcoxon matched-pairs signed-rank test. For all tests, $\mathrm{p} \leq$ 0,05 was considered significant.

\section{Results}

After 7 days of treatment, 53\% of patients showed improvements of their symptoms and signs ( $\mathrm{p}<0.0001)$. With continued treatment through day 14, symptoms control was achieved in $76 \%$ of patients $(\mathrm{p}<0.0001)$. Moreover, administration of $0,05 \%$ ketotifen eye drops for thirty days significantly $(\mathrm{p}<0.0001)$ reduced the TSSS for each patient (Figure 1) between days 0 and 30.

Treatment with this drug has clinical effect on burning, watery discharge, and swelling, particularly, at the end of the treatment. Every other symptom were significantly reduced ( $\mathrm{p}<0.016$ ) at any time of clinical evaluation (Figure 2). 


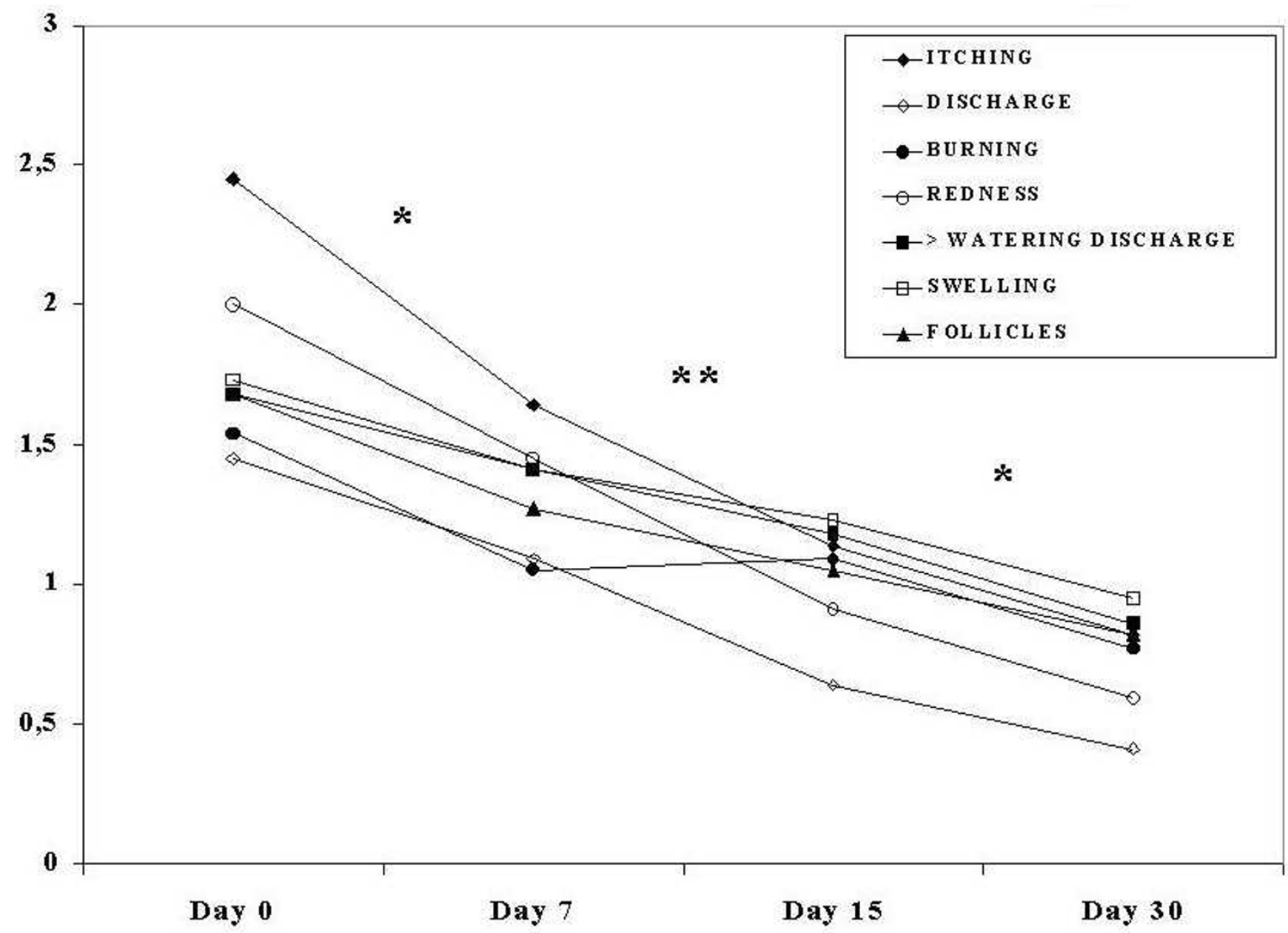

Figure 2

Variation of total score of symptoms and signs with ketotifen treatment. The differences between time points were analyzed by Wilcoxon signed-rank test (*, $\mathrm{p}<0.016$, day 0 vs 7,15 and 30 ; day 7 vs 30 , and day 15 vs $30 ; * *$, $p<0.031$, day 7 vs I5).

The effect of the treatment was also studied on the expression of different molecules on CD45 negative cells (EC) by FACS. It is worth to note that cells studied which were obtained by conjunctival scraping never contain more than $3 \%$ of CD 45 + cells (data not shown).

When the expression of HLA-DR, CD29 and eotaxin on EC was evaluated after the treatment we found a drop in the percentage of those positive EC in 58\%, 68\% and $73 \%$ of patients, respectively. Although the variation in percentage of HLA-DR+ EC was not significant, the percentage of CD29+ and eotaxin + EC significantly decreased ( $\mathrm{p}$ $<0.0062$ and $<0.0082$, respectively) at the end of the treatment (Table 1). In 9/19 patients a simultaneous drop in EC positive for CD29 and eotaxin was observed. Figure 3 shows a representative case from this group of patients.
We did not find any correlation between variations in mean fluorescent intensity and percentage of positive EC for these markers before and after the treatment.

\section{Discussion}

$\mathrm{AC}$ is a common, prevalent, and clinically significant IgE mediate hypersensitivity response in which signs and symptoms associated with the progression from early to late phase reaction start four to eight hours after challenge and persist up to 24 hours. The clinical reaction is accompanied by a significant recruitment of inflammatory cells (mainly neutrophils) in tears 20 minutes after challenge, and eosinophils and lymphocytes 6 to 24 hours after challenge [32]. In the chronic and more severe forms of $\mathrm{AC}$, other mechanisms and cells contribute to a more complex clinical profile [33]. In addition, the mast cell is consid- 

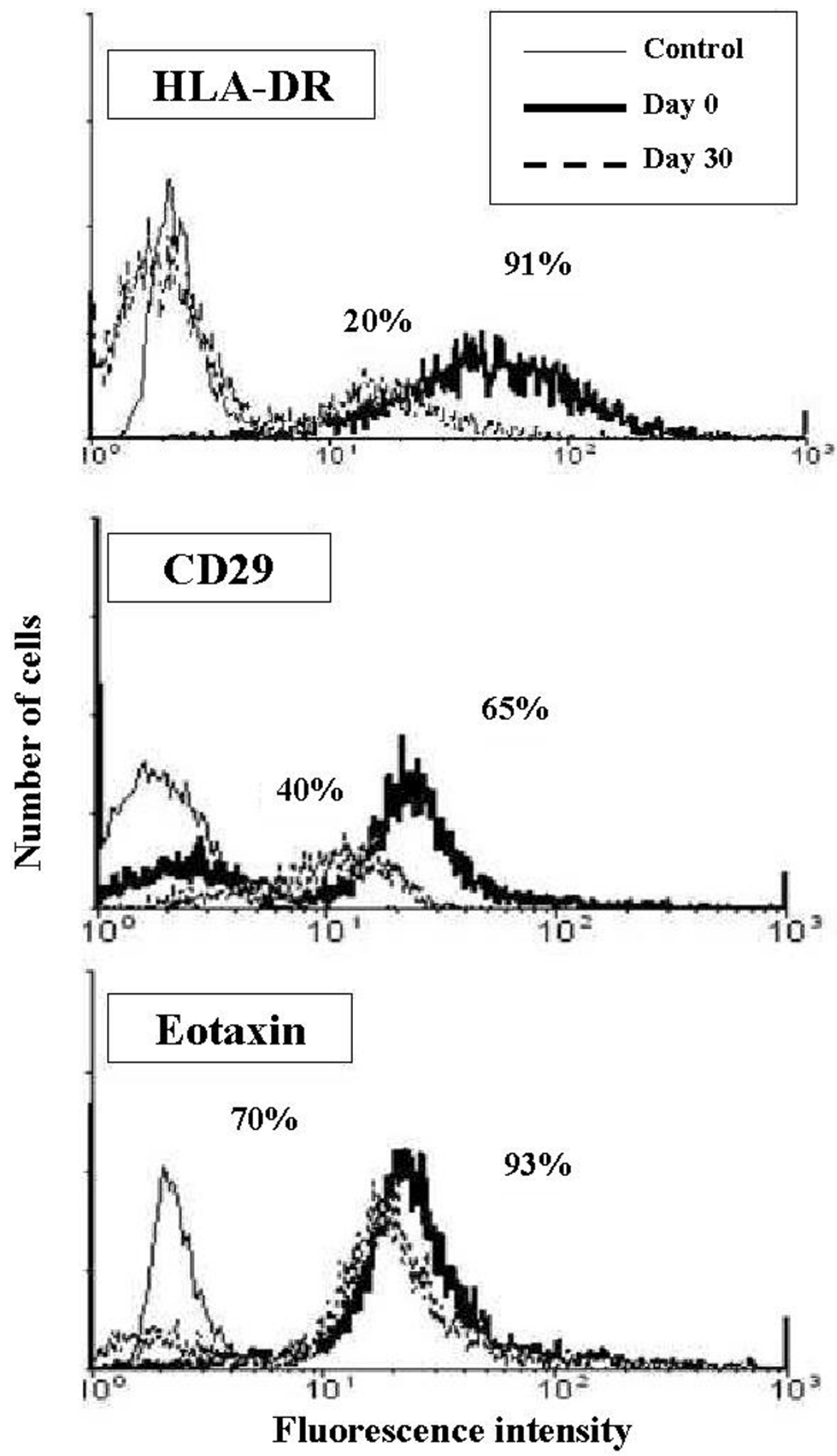

Figure 3

HLA-DR, CD29 and eotaxin expression by EC from patients with AC before and after the treatment with ketotifen fumarate $\mathbf{0 . 0 5} \%$. Data show one representative case from nine patients who had a simultaneous drop in CD29+ and eotaxin+ EC. 
Table I: Percentage of positive EC before and after the treatment with ketotifen fumarate $0.05 \%$.

\begin{tabular}{|c|c|c|c|c|c|c|}
\hline \multirow[t]{2}{*}{ Patients } & \multicolumn{2}{|c|}{ HLA-DR positive cells* } & \multicolumn{2}{|c|}{ CD29 positive cells* } & \multicolumn{2}{|c|}{ Eotaxin positive cells* } \\
\hline & Day 0 & Day 30 & Day 0 & Day 30 & Day 0 & Day 30 \\
\hline 1 & 60 & 30 & 82 & 38 & 69 & 52 \\
\hline 2 & 18 & 31 & 67 & 34 & 81 & 66 \\
\hline 3 & 50 & 34 & 86 & 70 & 75 & 64 \\
\hline 4 & 46 & 30 & 59 & 27 & 83 & 69 \\
\hline 5 & 10 & 65 & 61 & 50 & 86 & 64 \\
\hline 6 & 45 & 80 & 81 & 73 & 85 & 84 \\
\hline 7 & 12 & 55 & 78 & 45 & 98 & 72 \\
\hline 8 & 75 & 32 & 85 & 25 & 94 & 83 \\
\hline 9 & 91 & 19 & 65 & 51 & 93 & 70 \\
\hline 10 & 32 & 70 & 36 & 54 & 51 & 66 \\
\hline 11 & 21 & 11 & 64 & 13 & 68 & 82 \\
\hline 12 & 24 & 27 & 22 & 23 & 74 & 60 \\
\hline 13 & 20 & 12 & 17 & 24 & 76 & 65 \\
\hline 14 & 62 & 31 & 81 & 37 & 63 & 72 \\
\hline 15 & 55 & 72 & 54 & 83 & 77 & 57 \\
\hline 16 & 82 & 41 & 91 & 41 & 81 & 89 \\
\hline 17 & 80 & 3 & 75 & 80 & 84 & 72 \\
\hline 18 & 67 & 11 & 81 & 48 & 79 & 84 \\
\hline 19 & 17 & 63 & 42 & 45 & 76 & 56 \\
\hline Media & 46 & 38 & 64 & 45 & 79 & 70 \\
\hline SD & 26 & 23 & 22 & 19 & II & 10 \\
\hline
\end{tabular}

* See Methods.

ered to play a pivotal role in causing signs and symptoms since Bacon AS et al found increased levels of histamine, tryptase, PGD2, and leukotriene C4 in the tears of patients with Seasonal Allergic Conjunctivitis after conjunctival allergen challenge [34].

It is now becoming clear that EC may be viewed as active participants in the regulation of inflammation and leukocyte behavior. EC from a number of mucosal sites have been shown to be capable of: 1) expressing adhesion molecules like ICAM-1 (CD54) or beta 1 integrin (CD29), which are important for leukocyte emigration into tissue; 2) expressing MHC class II molecules and 3) synthesizing and releasing prostaglandins and leukotrienes which attract and activate leukocytes and 4) producing a variety of pro-inflammatory cytokines and chemokines. The adhesion molecules expressed on EC not only allow interactions between cells and cells with matrix but also they might be involved in intracellular signals [12,13,35-37].

Although we did not found significant variations in the percentage of HLA-DR+ EC before and after treatment, the majority of patients exhibited a significant decrease in the percentage of CD29+ cells suggesting that the expression of these molecules are controlled by different mechanisms.
Eotaxin, a CC chemokine, is a potent and selective eosinophil chemoattractant to the site of inflammation but also plays an important role in damaging tissue by its capacity to induce the release of reactive oxygen species $[38,39]$. It has been previously demonstrated that eotaxin mRNA and protein are constitutively expressed by bronchial and nasal epithelium from normal individuals and increased within the airways of asthmatic individuals, and in nasal biopsy specimens from individuals with allergic rhinitis. In addition eotaxin immunoreactivity was found in macrophages, eosinophils, T cells, mast cells, and neutrophils, suggesting that this chemokine is an important mediator in the physiological and pathological trafficking of eosinophils [40,41].

It has been reported that in EC from normal conjunctival biopsies there is a weak cytoplasmic expression of eotaxin [13]. In our study we found a strong expression of eotaxin on EC from patients with AC which decrease significantly after treatment with ketotifen.

Current therapy of ocular allergic disease focuses on allergen elimination, modulation of the immune system and pharmacological inhibition of the chemical mediators involved in the immune response. The most commonly used therapeutic option is the pharmacological inhibition of chemical mediators. Mast cells stabilizers and antihista- 
mines are two of the most commonly used group of therapeutic agents; they stabilize the mast cell membranes by preventing calcium influx across the mast cell membranes, thereby preventing mast cell degranulation and mediator release and the new antihistamines have been demonstrated to be capable of affecting several phenomena of the allergic inflammation, including mediator release, cellular activation and adhesion molecule expression $[42,43]$. Among these drugs, ketotifen fumarate, attenuated the local allergic reaction in patients with AC $[20,21]$ and the efficacy and safety of this drug in AC management has also been shown in human conjunctival allergen challenge model $[44,45]$.

Here, we corroborated the effectiveness of ketotifen fumarate in decreasing the symptoms and signs of $\mathrm{AC}$ in the majority of patients, but more importantly we showed that this drug even though was not effected in reducing the expression of HLA-DR on EC, it significantly decreased the percentage of CD29+ and eotaxin+ EC.

The mechanism of action by which this drug produce this effects are probably related to the decrease amounts of inflammatory cytokines/chemokines released by effector cells at the conjunctival level. Clearly, additional studies are needed to fully understand the complex mechanisms of the anti-inflammatory effect of Ketotifen fumarate in patients with AC.

\section{List of abbreviations}

$\mathrm{AC}=$ Allergic Conjunctivitis.

$\mathrm{EC}=$ Epithelial cells

TSSS $=$ Total symptoms and signs score

$\mathrm{mAb}=$ Monoclonal antibody.

\section{Competing interests}

None declared.

\section{Authors' contributions}

Martín AP: collected conjunctival scrapings and carried out immunofluorescence studies, performed the statistical analysis and drafted the manuscript.

Urrets-Zavalia J: performed the ophthalmological evaluation of the patients with AC.

Berra A: performed conjunctival cytology studies and quantification of tear IgE.

Mariani AL: carried out the quantification of serum IgE, secretory IgA and lisozime.
Gallino N: carried out the prick tets and clinical evaluation of the patients with AC.

Gomez Demel E: performed the ophthalmological evaluation of the patients with AC.

Gagliardi J: carried out the prick tets and clinical evaluation of the patientswith AC.

Baena-Cagnani CE: carried out the prick tets and clinical evaluation of the patientswith AC.

Urrets-Zavalia E: conceived of the study, and participated in its design and coordination.

Serra, HM: conceived of the study, and participated in its design and coordination.

\section{Acknowledgements}

We wish to thank the excellent technical assistance of Yanina Eberhard and Pablo Romagnoli.

\section{References}

I. A Solomon, Pe'er J and Levi-Schaffer F Advances in ocular allergy: basic mechanisms, clinical patterns and new therapies. Curr Opin Allergy Clin Immunol 200 I, I:477-482

2. Bielory $L$ Update on Ocular Allergy Treatment. Expert Opin Pharmacother 2002, 3:54I-553

3. Abelson MB, George MA and Garofalo $C$ Differential diagnosis of ocular disorders. Ann Allergy 1993, 70:95-109

4. MacLeod JD, Anderson DF, Baddeley SM, Holgate ST, McGill JF and Roche WR Immunolocalization of cytokines to mast cells in normal and allergic conjunctiva. Clin Exp Allergy 1997, 27:13281334

5. Irani AM Ocular mast cells and mediators in ocular allergy. In: Immunology and allergy clinics of North America (Edited by: Bielory) Philadelphia, WB Saunders 1997, I-13

6. MacDonald SM Histamine-releasing factor. Curr Opin Immunol 1996, 8:778-783

7. Desreumaux $P$ and Capron $M$ Eosinophils in allergic reactions. Curr Opin Immunol 1996, 8:790-795

8. Anderson DF, MacLeod JD, Baddeley SM, Bacon AS, McGill JI, Holgate ST and WR Roche Seasonal allergic conjunctivitis is accompanied by increase mast cell numbers in the absence of leukocyte infiltration. Clin Exp Allergy 1997, 27:1060-1066

9. Fujihara T, Takeuchi T, Saito K and Tsuboda K Flow cytometric analysis of surface antigens on human conjunctival epithelial cells. Ophthalmic Res 1997, 29:103-109

10. Avunduk AM, Avunduk MC, Dayioglu YS and Centinkaya K Flow cytometric tear analysis in patients with chronic allergic conjunctivitis. Jpn J Ophthalmol 1997, 41:67-70

II. Vorkauf M, Duncker G, Nolle B and Sterry W Adhesion molecules in normal human conjunctiva. An immunohistological study using monoclonal antibodies. Graefes Arch Clin Exp Ophthalmol 1993, 23I:323-330

12. Hingorani M, Calder V, Buckley RJ and Lightman S The Role of Conjunctival Epithelial Cells in Chronic Ocular Allergic Disease. Exp. Eye Res 1998, 67:491-500

13. Abu El-Asrar AM, Struyf S, Al-Kharashi SA, Missotten L, Van Damme $J$ and Geboes $K$ Chemokines in the limbal form of vernal keratoconjunctivitis $\mathrm{Br}$ J Ophthalmol 2000, 84:1360-1366

14. Garcia-Zepeda EA, Rothenberg ME, Ownbey RT, Celestin J, Leder P and Luster $A D$ Human eotaxin is a specific chemoattractant for eosinophil cells and provides a new mechanism to explain tissue eosinophilia. Nat Med 1996, 2:449-456

15. Abelson MB, Allansmith MR and Friedlaender MH Effect of topically applied ocular decongestant and antihistamine. Am J Ophthalmol 1980, 90:254-257 
16. Naclerio RM Optimizing treatment options. Clin Exp Allergy 1998, 28:54-59

17. Joss JD and Craig TJ Seasonal allergic conjunctivitis: overview and treatment update. J Am Osteopath Assoc 1999, 99:SI3-I8

18. Friedlaender $\mathrm{MH}$ The current and future therapy of allergic conjunctivitis. Curr Opin Ophthalmol 1998, 9:54-58

19. Grant SM, Goa KL, Fitton A and Sorkin Ketotifen EM A review of its pharmacodynamic and pharmacokinetic properties, and therapeutic use in asthma and allergic disorders. Drugs 1990 40:4I 2-448

20. Mimura $Y$ Clinical efficacy and optimal concentration of ketotifen ophthalmic solution on allergic conjunctivitis and vernal conjunctivitis. J Clinical Ther Med 1989, 5:709-72I

21. Aguilar AJ Comparative study of clinical efficacy and tolerance in seasonal allergic conjunctivitis management with $0.1 \%$ olopatadine hydrochloride versus $\mathbf{0 . 0 5 \%}$ ketotifen fumarate. Acta Ophthalmol Scand Suppl 2000, 230:52-55

22. Kabra SK, Pandey RM, Singh R and Seth V Ketotifen for asthma in children aged 5 to 15 years: a randomised placebo-controlled trial. Ann Allergy Asthma Immunol 2000, 85:46-52

23. Hoshino M, Nakamura Y, Sim JJ and Tomioka H A comparative study of the effects of ketotifen, disodium cromoglycate, and beclomethasone dipropionate on bronchial mucosa and asthma symptoms in patients with atopic asthma. Respir Med 1998, 92:942-950

24. Miki I, Kusano A, Ohta S, Hanai N, Otoshi M, Masaki S, Sato S and Ohmori K Histamine enhanced the TNF-alpha-induced expression of E-selectin and ICAM-I on vascular endothelia cells. Cell Immunol 1996, I 7 I:285-288

25. Ciprandi G, Buscaglia S, Pesce G, Passalacqua G, Rihoux JP, Bagnasco $M$ and Canonica GW Cetirizine reduces inflammatory cell recruitment and ICAM-I (or CD54) expression on conjunctival epithelium in both early- and late-phase reactions after allergen-specific challenge. A Allergy Clin Immunol 1995, 95:6I2-62 I

26. Bagnasco $\mathrm{M}$ and Canonica GW Influence of $\mathrm{HI}$-receptor antagonists on adhesion molecules and cellular traffic. Allergy 1995 50(24 Suppl):17-23

27. Ciprandi G, Buscaglia S, Pronzato C, Benvenuti C, Cavalli E, Bruzzone $\mathrm{F}$ and Canonica GW Oxatomide reduces inflammatory events induced by allergen-specific conjunctival challenge. Ann Allergy Asthma Immunol 1995, 75:446-452

28. Ciprandi G, Pronzato C, Ricca V, Varese P, Del Giacco GS and Canonica GW Terfenadine exerts antiallergic activity reducing ICAM-I expression on nasal epithelial cells in patients with pollen allergy. Clin Exp Allergy 1995, 25:87।-878

29. Vignola AM, Crampette L, Mondain M, Sauvere G, Czarlewski W, Bousquet J and Campbell AM Inhibitory activity of loratadine and descarboethoxyloratadine on expression of ICAM-I and HLA-DR by nasal epithelial cells. Allergy 1995, 50:200-203

30. Friedlaender MH Conjunctivitis of Allergic origin: Clinical presentation and differential diagnosis. Surv Ophthalmol 1993 , 38:105-114

31. Martín A, Gagliardi J, Gomez Demel E, Berra A, Gallino N, Daraio MC, Copello A, Urrets-Zavalia J, Mariani AL, Urrets-Zavalia E and Serra HM Toward the best diagnosis of allergic conjunctivitis. Archivos de Alergia e Inmunología Clínica 200I, 32:16-25

32. Bonini S and Ghinelli E The Early and Late Phase of the Ocular Allergic Reaction. Acta Ophthalmol Scand 2000, 78:41

33. Abelson MB and Udell II Allergic and toxic reactions. In: Principles and Practice of Ophtalmology: Clinical Practice Philadelphia: WB Saunders Company 1994, 77-100

34. Bacon AS, Ahluwalia P, Irani AM, Schwartz LB, Holgate ST, Church $M K$ and McGill JI Tear and conjunctival changes during the allergen-induced early and late phase responses. J Allergy Clin Immunol 2000, 106:948-954

35. Abu El-Asrar AM, Geboes K, Al-Kharashi S, Al-Mansouri S, Missotten $L$ and Geboes $K$ Adhesion molecules in vernal keratoconjunctivitis. Br J Ophthalmol 1997, 8I: 1099-1 I 06

36. Bacon AS, McGill Jl, Anderson DF, Baddeley S, Lightman SL and Holgate ST Adhesion molecules and relationship to leukocyte levels in allergic eye disease. Invest Ophthalmol Vis Sci 1998, 39:322330

37. Ciprandi G, Buscaglia S, Pesce G, Bagnasco M and Canonica GW Allergic subjects express intercellular adhesion molecule-I (ICAM-I or CD54) on epithelial cells of conjunctiva after allergen challenge. J Allergy Clin Immunol 1993, 9 I:783-792
38. Jose PJ, Griffiths-Johnson DA, Collins PD, Walsh DT, Moqbel R, Totty NF, Truong O, Hsuan JJ and Williams TJ Eotaxin: a potent eosinophil chemoattractant cytokine detected in a guinea pig model of allergic airways inflammation. I Exp Med 1994 I79:88I-887

39. Elsner J, Hochstetter R, Kimmig D and Kapp A Human eotaxin represents a potent activator of the respiratory burst of human eosinophils. Eur J Immunol 1996, 26:1919-1915

40. Taha RA, Minshall EM, Miotto D, Shimbara A, Luster A, Hogg JC and Hamid QA Eotaxin and monocyte chemotactic protein-4 mRNA expression in small airways of asthmatic and nonasthmatic individuals. A Allergy Clin Immunol 1999, 103:476-483

4I. Minshall EM, Cameron L, Lavigne F, Leung DY, Hamilos D, Garcia-Zepada EA, Rothenberg M, Luster AD and Hamid Q Eotaxin mRNA and protein expression in chronic sinusitis and allergen-induced nasal responses in seasonal allergic rhinitis. Am J Respir Cell Mol Biol 1997, I 7:683-690

42. Abelson $M B$ and Schaefer $K$ Conjunctivitis of allergic origin: Immunologic mechanims and current approaches to therapy. Surv Ophthalmol 1993, 38(suppl): I I5- I 27

43. Ciprandi G, Passalacqua $\mathbf{G}$ and Canonica GW Effects of $\mathbf{H I}$ antihistamines on adhesion molecules: a possible rationale for longterm treatment. Clin Exp Allergy 1999, 29(Suppl 3):49-53

44. Berdy GJ, Spangler DL, Bensch G, Berdy SS and Brusatti RC A comparison of the relative efficacy and clinical performance of olopatadine hydrochloride $0.1 \%$ ophthalmic solution and ketotifen fumarate $0.025 \%$ ophthalmic solution in the conjunctival antigen challenge model. Clin Ther 2000, 22:826-833

45. D'Arienzo PA, Leonardi A and Bensch G Randomized, doublemasked, placebo-controlled comparison of the efficacy of emedastine difumarate $\mathbf{0 . 0 5 \%}$ ophthalmic solution and ketotifen fumarate $0.025 \%$ ophthalmic solution in the human conjunctival allergen challenge model. Clin Ther 2002, 24:409416

\section{Pre-publication history}

The pre-publication history for this paper can be accessed here:

http://www.biomedcentral.com/1471-2415/3/2/prepub
Publish with Bio Med Central and every scientist can read your work free of charge

"BioMed Central will be the most significant development for disseminating the results of biomedical research in our lifetime. "

Sir Paul Nurse, Cancer Research UK

Your research papers will be:

- available free of charge to the entire biomedical community

- peer reviewed and published immediately upon acceptance

- cited in PubMed and archived on PubMed Central

- yours - you keep the copyright
BiolMedcentral 